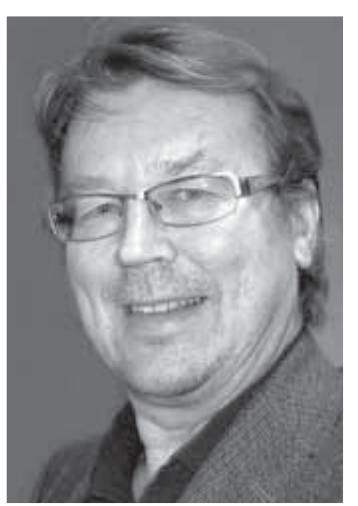

\section{TALOUSKASVUN OPIT}

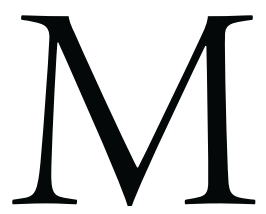

aailmantalouden ongelmat ja epävarmuustekijät ovat viimeistään vuonna 2011 tulleet jokaisen kansalaisen arkipäivään. Talouskasvun edistämisen nimissä pitäisi kiristää vyötä ja tehdä vähemmällä enemmän. Niin kansalliset hallitukset kuin ylikansalliset poliittiset toimijat joutuvat päätöksiä tehdessään ottamaan huomioon ennen muita sijoittajien toiveet. Politiikkaa tehdään sijoittajia lepytellen. Kansalaisia ahdistaa se, miten sijoittajien reaktio uusia hallituskoalitioita, päättäjiä ja päätöksiä kohtaan vaikuttaa työllisyyteen. Politiikan vaihtoehdottomuus perustuu sijoittajien ja rahanlainaajien mieltymyksiin. Kun sijoittajat ja rahanlainaajat nyökyttelevät tyytyväisinä, on tehty oikeita päätöksiä. Muu on väärää politiikkaa. Harjoitettua politiikkaa voidaan arvioida sen perusteella, kuinka suuria voittoja sijoittajat saavat sijoituksistaan ja kuinka pienellä riskillä rahanlainaajat voivat hakea hyvää tuottoa rahalleen. On edistettävä talouskasvua, kohennettava kansainvälistä kilpailukykyä, lisättävä työn ja tuotannon tehokkuutta, tehtävä pidempää työuraa, saatava uudet sukupolvet nuorempina töihin, lyhennettävä koulutusaikoja, keskityttävä koulutuksessa olennaiseen.

KOULUTUS ON KESKEINEN Osa talouskasvun ja kilpailukyvyn edistämistä. Kilpailukyvyn ja elinikäisen oppimisen diskurssit ovat ideologisesti yhtä. Hallit-

\section{P̈̈̈̈KIRJOITUS}

seva elinikäisen oppimisen diskurssi tuottaa yksilötasolla samaa ideologiaa kuin kansallisen kilpailukyvyn diskurssi hallitusten ja kansallisvaltioiden tasolla. Molemmat ovat onnistuneet nousemaan lähelle totuutta. Molemmat ovat iskusanoiksi lyhennettyjä argumentaatioita, jotka pyrkivät vakuuttamaan kuulijansa tullakseen itsestään selväksi osaksi heidän uskomusjärjestelmäänsä. Kumpaakin diskurssia luonnehtii tiettyyn yhteisöön kuulumisen luonnollisuutta korostava ja 'meidän' olemassaolostamme huolta kantava retoriikka. Kuullessamme iskusanat 'kansallisen kilpailukyky' muistamme, miten vakavasti uhattu kansantaloutemme ja kansakuntamme on, ja miten meidän kaikkien on uhrautuen kannettava kortemme yhteiseen kekoon suomalaisen teollisuuden ja vientiyritysten menestymisen puolesta. Sanapari 'elinikäinen oppiminen' taas muistuttaa meitä yksilöllisistä vajavaisuuksistamme ja siitä, miten meidän on toimittava säilyttääsemme työpaikkamme ja elintasomme sekä palvellaksemme taloutta ja edistääksemme kasvua.

CHICAGON YLIOPISTON OIKEUSTIETEEN ja etiikan professori Martha C. Nussbaum esittää kirjassaan Talouskasvua tärkeämpää (Gaudeamus) tärkeitä huomioita koulutuksen suunnanmuutoksista. Hänen mukaansa liiaksi talouden ja tuottavuuden argumentteihin perustuva koulutuspolitiikka johtaa typistyvään ja yksiulotteiseen ihmiskuvaan. Kun aineellisen hyö- 
dyn tavoittelu on saanut maiden hallitukset asettamaan luonnontieteet ja tekniikan muita oppiaineita ja koulutusaloja tärkeämpään asemaan, lyödään laimin osaamista, joka on demokratian toimivuuden, humanistisen sivistyksen ja suvaitsevaisuuden kannalta ensiarvoisen tärkeää. Hyödyllisiksi koneen osiksi kasvatetut sukupolvet eivät kykene itsenäiseen ajatteluun, perinteiden kriittiseen arviointiin, eivätkä asettumaan toisenlaista elämää elävien ihmisten asemaan. Demokratiassa tarvittavaa osaamista voidaan kehittää pitämällä huoli humanististen ja taideaineiden asemasta opetussuunnitelmissa ja koulutustarjonnassa niin perus- ja keskiasteella kuin korkeakouluissakin. Nussbaumin arvion mukaan lähes kaikissa maailman maissa vähennetään humanististen ja taideaineiden osuutta opetuksesta. Päättäjien mielestä ne ovat turhia rönsyjä, ja maailmanmarkkinoilla menestyminen edellyttää luopumista kaikesta hyödyttömästä. Lyhyen aikavälin hyötyjen tavoittelun vuoksi suositaan pitkälle erikoistuneita käytännön soveltajia.

NYKYIHMISET OVAT edeltäjiään paljon suoremmin riippuvaisia lajitovereistaan, joita eivät ole koskaan tavanneet. Taloudelliset, ekologiset, uskonnolliset ja poliittiset ongelmat ovat maailmanlaajuisia, eikä niiden ratkaisemista ole toivoakaan ilman yhteisiä ponnisteluja. Koulutuksen pitäisi valmentaa ihmisiä keskustelemaan mielekkäästi näistä kysymyksistä. Globaali talous on tehnyt meistä kaikista osallisia etäisimpienkin ihmisten elämään. Nussbaum (s.98) varoittaa: ”Jos kansainväliselle yhteistoiminnalle ei anneta vahvaa perustaa kouluissa ja yliopistoissa, ihmisten välinen vuorovaikutus luultavasti hoidetaan markkinoilla tapahtuvaa vaihtoa säätelevien kapeaalaisten normien mukaan. Silloin ihmiset nähdään ennen muuta hyödyntavoittelun välineiksi. Maailman kaikille kouluille ja korkeakouluille lankeaa siksi työläs ja kiireellinen tehtävä: lapset ja nuoret tulee opettaa katsomaan itsensä heterogeenisen kansakunnan (kaikki nykyaikaiset kansakunnat näet ovat heterogeenisiä) ja vielä heterogeenisemmän ihmiskunnan jäseniksi sekä ymmärtämään maailmaa kansoittavien ryhmien historiaa ja luonnetta."

VAROITUKSEN SANAT tulevat kreivin aikaan: Telluksen asukasluku ylitti juuri seitsemän miljardia, ja maailman johtajat huutavat apua talouskasvun lisäämiseksi. Talouskasvu ei onnistu vain tuotantoa ja tuottavuutta kasvattamalla. Kuluttaja-kansalaisten on myös ostettava kaikki tuotettu tavara. Kestävän kehityksen professori Tim Jackson Surreyn yliopistosta on hahmotellut uudenlaista rajallisen planeetan taloustiedettä kirjassaan Hyvinvointia ilman kasvua. Ensinnäkin on määriteltävä ihmisen toiminnan ekologiset rajat. Toiseksi on korjattava loputtomaan kasvuun perustuva, harhainen taloustiede ja luovuttava BKT:n palvonnasta. Kolmanneksi on muutettava kulutusyhteiskunnan vahingollinen sosiaalinen logiikka, mikä edellyttää muun muassa työn uudelleen jakamista ja konsumerismin eli kulutuskulttuurin purkamista.

Heikki Silvennoinen 